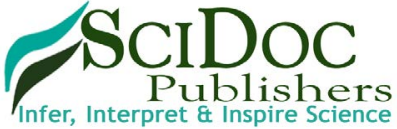

International Journal of Marine Science and Ocean Technology (IJMO)

ISSN: 2577-4395

\title{
Levels of Bio-Indicator Bacteria Transported To The Black Sea By The Riva Stream, Istanbul, Turkey
}

Research Article

Altug G*, Gurun S, Ciftci Türetken Ps, Kalkan S

Fisheries Faculty, Marine Biology Department, Basic Science Division, Istanbul University, Istanbul, 34134, Turkey.

\section{Abstract}

In this study the levels of indicator bacteria and variable environmental conditions were investigated in the Riva Stream and transition zone of the Black Sea, Istanbul, Turkey. The surface water samples were taken from ten stations chosen regarding point-sources of pollution of the Riva Stream in the summer and winter season between the period June 2010 and August 2011. The membrane filtration technique was used to determine levels of total coliform and fecal coliform bacteria. Variable environmental parameters and water clarity were recorded in-situ. The results showed that obtained levels of indicator bacteria in all samples higher than the limit values for defined by national directive. A positive relationship between the indicator bacteria and temperature was recorded. The finding also showed that the Riva Stream under the influences of bacteriological pollution due to the fact that the fecal sources with respect to anthropogenic activities. Consequently, the Riva Stream contribute as a point-sourced bacterial pollutant factor to the villages located to the shores of the Riva Stream as well as the coast of the Turkish Black Sea and the beach located just west of Riva village. The pollution sources should be reduced and precautions must be taken for prevent potential problems related to ecosystem and human health. In this study, the first data related to the bacteriological load of the Riva Stream was obtained. However, there is a need long term monitoring studies to evaluate the effects of environmental variations and human impacts on the bio indicator bacteria in this areas.

Keywords : Bio-indicator bacteria; Riva Stream; Fecal Coliform; Total Coliform

\section{Introduction}

Despite of the presence of fecal coliforms in water may not be directly harmful; water contaminated with fecal coliforms may contain pathogenic bacteria and may be hazardous to human health. Fecal contamination carries an important role as a widespread hazard for public health [1]. As a result, indicator bacteria have traditionally been used for routine examination of surface water quality since the early 1970s, Water quality researchers relied almost exclusively on indicator bacteria including the coliform group, fecal streptococci, Escherichia coli (E. coli) and enterococci $[2,3]$. Due to the coastal zones are usually under intense anthropogenic pollution, microorganisms are accepted as the major factors for pollution. Domestic waste-water discharges are threats of the coastal environments worldwide considerably [4]. Coastal waters are under pressures of sewage waste-water discharge and disposal practices that may cause high nutrient levels, hazardous chemicals and pathogens causing diseases [5, 6,7]. Pathogens transmitted by human feces and the sewage systems polluted by human and animal pathogens as the main source of bacterial pollution. Total and fecal coliforms as well as fecal streptococci are traditionally used as universal microbiological indicators of water quality [8].

The Sea of Marmara is an inner sea, located between Asia and Europe continents. Istanbul Strait (Bosphorus) and Çanakkale Strait (Dardanelles) are gateways to the Aegean Sea and the Black Sea. Accordingly, it is important for fisheries industry, marine transportation and also ecosystem health [9].

The Riva Stream is approximately about $33 \mathrm{~km}$ and it flows through Riva village, Istanbul. The Riva Stream, one of the largest streams of Istanbul region, is located in exit of the Sea of MarmaraIstanbul between the Black Sea. Ömerli Dam was established on the Riva Stream in 1972 by DSI (General Directorate of State Hydraulic Works) to provide drinking water for the city as the biggest drinkable water reservoir $(23.5 \mathrm{~km} 2$ area, $62 \mathrm{~m}$ maximum

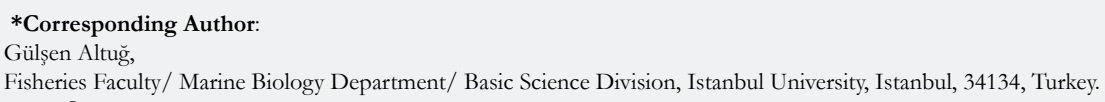

Citation: Altug G, Gurun S, Ciftci Türetken PS, Kalkan S (2016) Levels of bio-indicator bacteria transported to the Black Sea by the Riva Stream, Istanbul, Turkey. Int J Marine Sci Ocean Tecbnol. 3(5), 45-49. doi: http://dx.doi.org/10.19070/2577-4395-160008

Copyright: Altug $\mathbf{G}^{\circ}$ 2016. This is an open-access article distributed under the terms of the Creative Commons Attribution License, which permits unrestricted use, distribution and reproduction in any medium, provided the original author and source are credited. 
depth) of the northern part of the Marmara region, Turkey [10, 11].

The Riva basin is under the influences of settlements, recreational, domestic, agricultural and industrial activities. Previous studies, conducted in the Riva Stream related to the eutrophication and fisheries of the region, implied the occurrence of some pollutant inputs in the region $[12,10,11,13]$. However, there is no data related to indicator bacteria or bacterial pollution load of the Riva Stream transported to the Black Sea.

In this study, the presence of indicator organisms of bacterial pollution (total coliform, fecal coliforms) and its relationship with primary hydrographic parameters were investigated for the first time with an aim to detect transported indicator bacteria levels via the Riva Stream to the Black Sea, Turkey.

\section{Material and Methods}

The water samples taken under aseptic conditions from surface $(0-30 \mathrm{~cm})$ on 10 different stations in the different time periods between June 2010 and August 2011were transported daily to the Aquatic Microbial Ecology Laboratory of Faculty of Fisheries of Istanbul University.

The primary hydrographic parameters; salinity, temperature, $\mathrm{pH}$ and dissolved oxygen concentration were measured in-situ by using a portable Hach Lange Multiparameter (HQ 40D). Water clarity/underwater visibility was measured by using Secchi disk. Membrane filtration technique was used for bacteriological analyses. The water samples were filtered through a $0.45 \mu \mathrm{m}$ membrane filter with a metal vacuum filtering set (Millipore, Germany) and then the membrane filter was placed on m-Endo, $\mathrm{m}$-FC for total coliform and fecal coliform bacteria. The plates were incubated for $48 \mathrm{~h}$ (at $37 \pm 0.1^{\circ} \mathrm{C}$ and $44.5 \pm 0.1^{\circ} \mathrm{C}$ ) and then the colonies on the plates were evaluated [14].

Blue colonies which grew on m-FC medium were evaluated to be fecal coliform suspicious; pink-red colonies with yellowgreen metallic shininess which grew on m-Endo medium were evaluated as coliform suspicious. The correction tests were done for the suspicious colonies. Cytochrome oxidase test (API Strep, BioMerieux) was applied to coliform suspicious colonies and oxidase negative colonies were counted to be coliform. Cytochrome oxidase and indole (HIMEDIA) tests were applied to fecal coliform suspicious colonies, and oxidase negative and indole positive colonies were counted to be fecal coliform bacteria. The results were expressed to be the colony formed unit in $100 \mathrm{ml}$; (CFU/100 mL) [15,14].

Location of Riva Stream and the sampling stations were shown in Figure 1. The photographs taken from the sampling areas of the Riva Stream were displayed in Figure 2

\section{Figure 1. Location of Riva Stream and the sampling stations.}

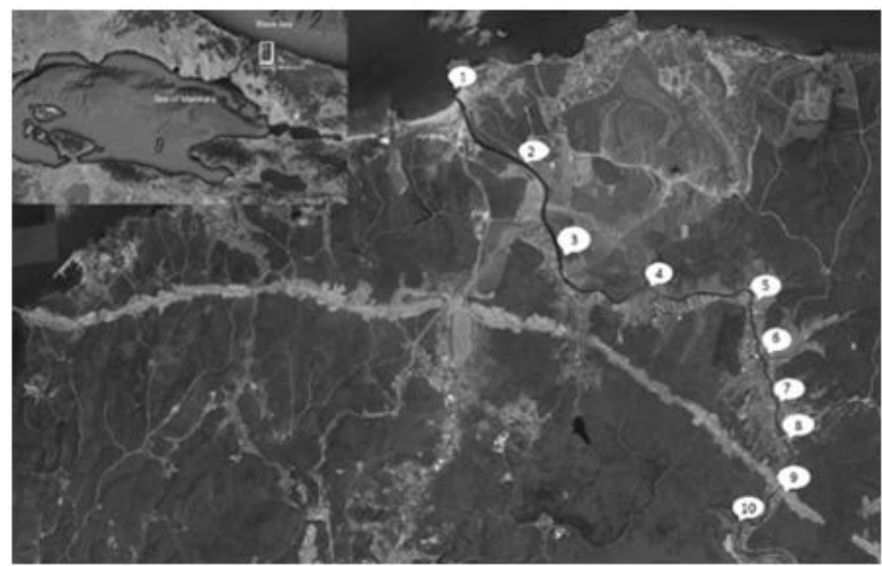

Figure 2. The photographs taken from the sampling areas of the Riva Stream.

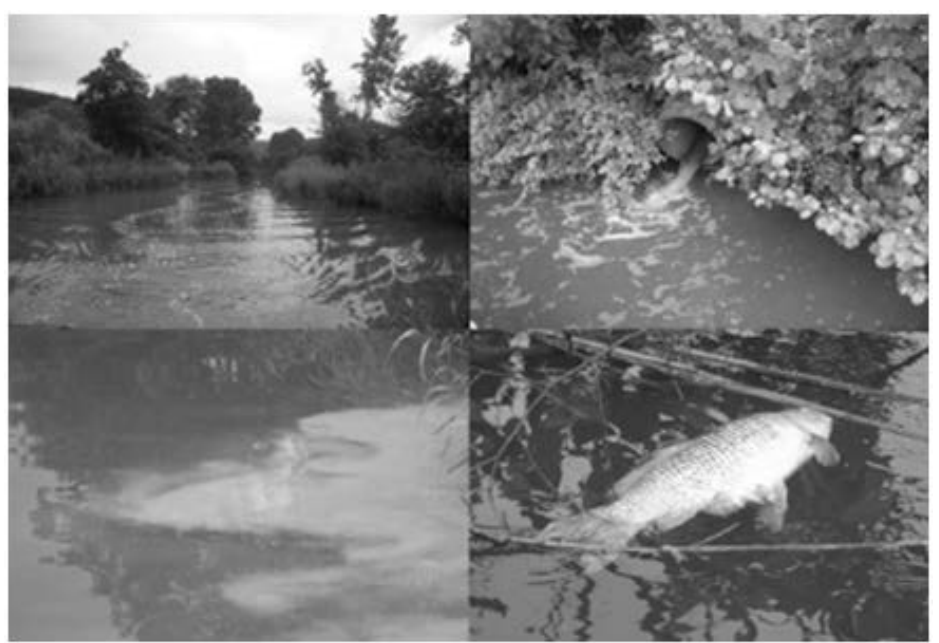




\section{Results}

The physicochemical parameters of the sampling areas; dissolved oxygen, temperature, salinity, $\mathrm{pH}$ and also Secchi disc depth were shown on Table 1.

The minimum and maximum degrees Celsius values for temperature were 8.8-25.8, \%o values for salinity were 5-86-0.24, $\mathrm{pH}$ values of the sampling stations were recorded to be 7.61-6.88, the milligrams per liter values for dissolved oxygen were 6.860.22. While the lowest meter values for Secchi disc were measured to be 0 , the highest Secchi disc values was 1 meter.

The levels of total coliform detected in the surface water samples during the study period were shown in Figure 3.

While the samples taken all stations were displayed higher coliform bacteria counts than the national limit values during the study period, the highest counts of the total coliform bacteria were detected in June 2010.

The levels of fecal coliform detected in the surface water samples during the study period were shown in Figure 4.

The levels of fecal coliform were detected higher than advised national limit values. The counts of the fecal coliform were recorded minimum $2.4 \times 10^{5} \mathrm{CFU} / 100 \mathrm{ml}$ and maximum $5.6 \times 10^{5}$ CFU/100 during the study period.

\section{Discussion}

In this study, levels of bacteria and the variable environmental parameters detected offer us data related to trophic status of the Riva Stream. The Secchi disk measurements used to indirectly estimate light penetrates through the water column of Riva Stream were found to conform to class IV (hypereutrophic) limit during the study period. The dissolved oxygen parameter is used to determine possible industrial based pollution. The water quality classes of Riva Stream in terms of dissolved oxygen values were detected as corresponding to class III and IV.

In this study detected bacteria levels in the surface water samples taken from the Riva Stream were also evaluated regarding usage style of the stream as a natural resource. The Riva Stream has importance because the upper course of it feeds Ömerli Dam, which provides more than forty percent of Istanbul's drinking water. In addition, the Riva Stream popular for recreational activities.

The area where Riva Stream flows into the sea is the popular beach of the Black Sea located just west of Riva village, Istanbul. The villages, farms, agricultural areas and touristic restaurants also have taken place on either side of the stream. In this study, detected bacterial pollution transported from the Riva Stream to the Black Sea and either side of the stream, in contrast to widely held recreational activities of the region, were evaluated as a potential risk for the region.

Figure 3. The levels of the total coliform bacteria detected in the surface water samples during the study period.

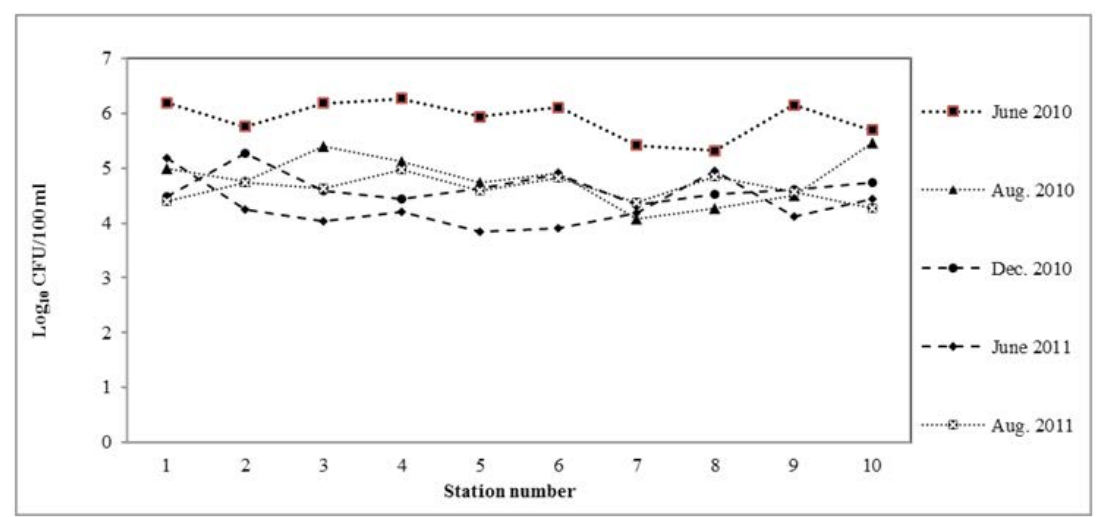

Figure 4. The levels of fecal coliform bacteria detected in the surface water samples during the study period.

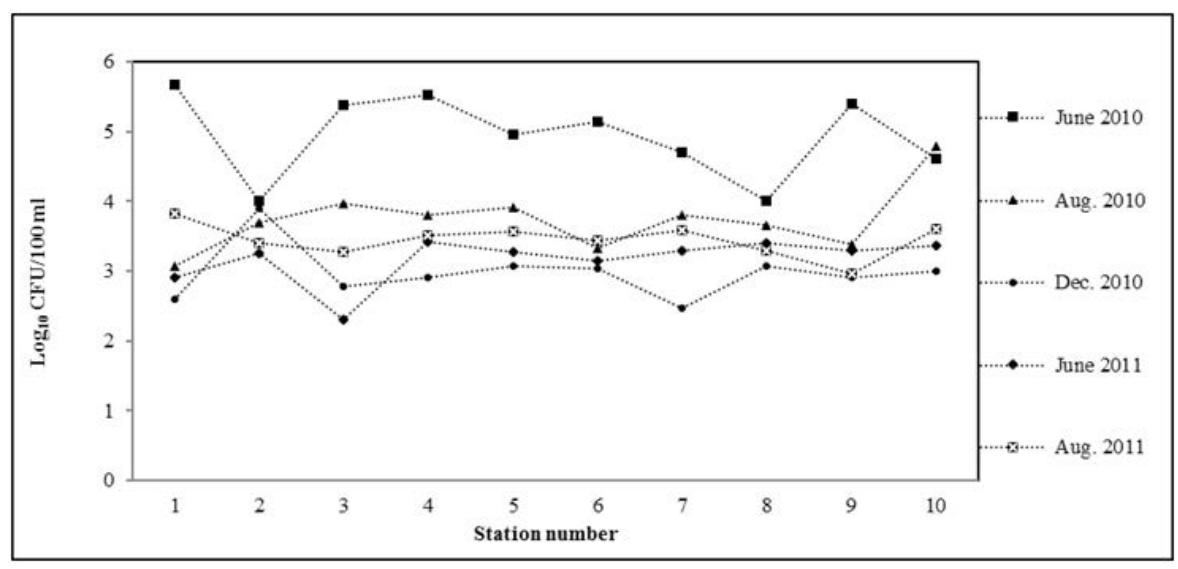


Table 1. Physicochemical parameters and Secchi disk depths on Riva Stream.

\begin{tabular}{|c|c|c|c|c|c|c|}
\hline Stations & Months & Temp $\left({ }^{\circ} \mathrm{C}\right)$ & Salinity (\%o) & $\mathrm{pH}$ & $\mathrm{O}_{2}(\mathrm{mg} / \mathrm{l})$ & $\mathrm{SD}(\mathrm{m})$ \\
\hline \multirow{5}{*}{ Station 1} & Jun-10 & 19.9 & 5.15 & 7.55 & 6.86 & 1 \\
\hline & Aug. 2010 & 24.4 & 6.2 & 7.52 & 5.11 & 0.5 \\
\hline & Dec. 2010 & 12.2 & 2.45 & 7.49 & 5.36 & 1 \\
\hline & Jun-11 & 20.4 & 4.49 & 7.48 & 6.05 & 1 \\
\hline & Aug. 2011 & 25.1 & 5.86 & 7.53 & 5.27 & 0.5 \\
\hline \multirow{5}{*}{ Station 2} & Jun-10 & 20.6 & 1.04 & 7.61 & 1.66 & 0.5 \\
\hline & Aug. 2010 & 25.3 & 2.02 & 7.5 & 2.6 & 1 \\
\hline & Dec. 2010 & 11 & 1.01 & 6.88 & 4.09 & 1 \\
\hline & Jun-11 & 20.7 & 1.02 & 7.4 & 3.86 & 0.5 \\
\hline & Aug. 2011 & 25.5 & 1.98 & 7.45 & 2.7 & 0.5 \\
\hline \multirow{5}{*}{ Station 3} & Jun-10 & 20.6 & 0.96 & 7.56 & 0.77 & 0.05 \\
\hline & Aug. 2010 & 25 & 1.5 & 7.55 & 1.4 & 0.5 \\
\hline & Dec. 2010 & 10.9 & 0.82 & 7.19 & 4.2 & 0.75 \\
\hline & Jun-11 & 20.3 & 1.02 & 7.31 & 1.1 & 0.5 \\
\hline & Aug. 2011 & 25.2 & 1.33 & 7.40 & 1.2 & 0.5 \\
\hline \multirow{5}{*}{ Station 4} & Jun-10 & 19.7 & 0.77 & 7.56 & 2.2 & 1 \\
\hline & Aug. 2010 & 25 & 1.2 & 7.55 & 2.96 & 0.5 \\
\hline & Dec. 2010 & 8.8 & 0.28 & 7.5 & 4.35 & 0.75 \\
\hline & Jun-11 & 19.5 & 0.85 & 7.51 & 2.65 & 1 \\
\hline & Aug. 2011 & 25.8 & 1.1 & 7.53 & 2.31 & 0.5 \\
\hline \multirow{5}{*}{ Station 5} & Jun-10 & 20.4 & 0.74 & 7.53 & 0.77 & 0.1 \\
\hline & Aug. 2010 & 25.1 & 1.05 & 7.55 & 1.3 & 0.5 \\
\hline & Dec. 2010 & 11.3 & 0.74 & 7.33 & 3.2 & 0.5 \\
\hline & Jun-11 & 19.9 & 0.89 & 7.5 & 0.99 & 0.5 \\
\hline & Aug. 2011 & 25.4 & 0.81 & 7.46 & 1.5 & 0.5 \\
\hline \multirow{5}{*}{ Station 6} & Jun-10 & 19.6 & 0.6 & 7.56 & 3.25 & 0.1 \\
\hline & Aug. 2010 & 24.5 & 0.95 & 7.54 & 0.97 & 0.5 \\
\hline & Dec. 2010 & 11.1 & 0.46 & 7.32 & 4.47 & 0.5 \\
\hline & Jun-11 & 19.3 & 0.72 & 7.49 & 2.5 & 0.25 \\
\hline & Aug. 2011 & 26 & 0.69 & 7.41 & 1.34 & 0.5 \\
\hline \multirow{5}{*}{ Station 7} & Jun-10 & 20.6 & 0.65 & 7.5 & 0.9 & 1 \\
\hline & Aug. 2010 & 24.4 & 0.84 & 7.52 & 0.52 & 0.5 \\
\hline & Dec. 2010 & 11 & 0.55 & 7.34 & 3.17 & 0.5 \\
\hline & Jun-11 & 20.4 & 0.68 & 7.48 & 1.15 & 1 \\
\hline & Aug. 2011 & 25.2 & 0.56 & 7.39 & 0.75 & 0.75 \\
\hline \multirow{5}{*}{ Station 8} & Jun-10 & 20.7 & 0.42 & 7.49 & 0.93 & 1 \\
\hline & Aug. 2010 & 24 & 0.59 & 7.54 & 0.27 & 0.5 \\
\hline & Dec. 2010 & 11.0 & 0.29 & 7.34 & 3.66 & 0.5 \\
\hline & Jun-11 & 20.4 & 0.41 & 7.52 & 1.69 & 1 \\
\hline & Aug. 2011 & 24.5 & 0.38 & 7.39 & 0.54 & 0.5 \\
\hline \multirow{5}{*}{ Station 9} & Jun-10 & 20.5 & 0.4 & 7.52 & 0.22 & 0.5 \\
\hline & Aug. 2010 & 25.2 & 0.45 & 7.53 & 0.49 & 0 \\
\hline & Dec. 2010 & 12.1 & 0.24 & 7.39 & 4.17 & 0.5 \\
\hline & Jun-11 & 24.8 & 0.3 & 7.57 & 0.86 & 0.5 \\
\hline & Aug. 2011 & 25.5 & 0.31 & 7.55 & 0.71 & 0.5 \\
\hline \multirow{5}{*}{ Station 10} & Jun-10 & 19.9 & 0.27 & 7.52 & 0.61 & 0.5 \\
\hline & Aug. 2010 & 24.8 & 0.3 & 7.57 & 0.86 & 0.5 \\
\hline & Dec. 2010 & 11.4 & 0.24 & 7.40 & 4.21 & 0.5 \\
\hline & Jun-11 & 20.2 & 0.33 & 7.41 & 0.89 & 0.5 \\
\hline & Aug. 2011 & 24.9 & 0.29 & 7.46 & 0.75 & 0.5 \\
\hline
\end{tabular}




\section{Conclusion}

In this study indicator bacteria counts were found higher than standard values in the all study area. Because of indicator bacteria may show the presence of pathogenic bacteria this area must be examined more carefully in order to understand bacterial pollution levels in all aspects on study area. Beside increasing human population, anthropogenic pollution, domestic and industrial wastes, fishing and shipping activities and also untreated discharge of sewage water from the coastal towns and farms are the main responsible pollutant factors of coastal waters on this area. Increasing human activities around the region such as populated areas, connection roads of the third bridge of Istanbul also contribute to the lower course of the stream. This may lead to economic loss and serious human health hazards due to interactions between Ömerli Dam-Reservoir, Riva Stream and coastal ecosystems in future. However, the data related to bacterial pollution in the Riva Stream has not previously been reported. In this preliminary study, the findings showed that there was no decrease in the level of bacteria in all stations throughout the sampling period. This situation in turn showed that bacterial pollution from terrestrial were continual. Pollution factors should be reduced and precautions methods must be arranged as soon as possible. There is a need for work to be done to promote the entirety of the ecosystem, sustainable use of sources, and control of pollution sources to protect human and ecosystem health.

\section{Acknowledgements}

The authors wish to thank to Mustafa KILINÇ for his logistically support to the field studies. The authors also thank Onnocan HULYAR for his help in sampling

\section{References}

[1]. Arnone RD, Walling JP (2007) Waterborne pathogens in urban watersheds. J Water Health, 5(1): 149-162.

[2]. Cabelli VJ (1977) Indicators of recreational water quality. Bacterial indicators/health hazards associated with water. ASTM STP 635: 222-238.

[3]. Cohen J, Shuval HI (1973) Coliforms, fecal coliforms, and fecal streptococci as indicators of water pollution. Water, Air, and Soil Pollution. 2(1): 85-95.

[4]. Anonymous (2001) GPA (The Global Programme of Action for the Protec- tion of the Marine Environment from Landbased Activities) (2001). Regional Working Group on Municipal Wastewater: Regional Cooperation for Innovative Action 1 - Ocho Rios, Jamaica, 19-21 February 2001.

[5]. Danulat E, Muniz P, Garcia-Alonso J, Yannicelli B (2002) First assessment of the highly contaminated harbour of Montevideo, Uruguay. Mar Pollut Bull. 44(6): 554-565.

[6]. Tyrrel SF (1999) The Microbiological Quality of Water Used for IrrigationIrrigation News. 27: 39-42.

[7]. Anonymous (2003) WHO (World Health Organization) Looking back: looking ahead: five decades of challenges and achievements in environmental sanitation and health.

[8]. Neil M (2004) Microbiological indices for total coliform and E. coli bacteria in estuarine waters. Mar Pollut Bull. 49(9-10): 752-760.

[9]. Altug G, Cardak M, Ciftci PS, Gurun S (2009) An Important Water Route Between Mediterranean and Black Seas and Bacterial Pollution (Canakkale and Istanbul Straits, Turkey) - Proceeding of the 3rd WSEAS Int. Conference on Waste Management, Water Pollution, Air Pollution, Indoor Climate. 466-471.

[10]. Tarkan AS (2010) Effects of Streams on Drinkable Water Reservoir: An Assessment of Water Quality, Physical Habitat and Some Biological Features of the Streams. Journal of FisheriesSciences.com.

[11]. Özuluğ M, Acıpınar H, Gaygusuz O, Gursoy C, Tarkan AS (2005) Effects of human factor on the fish fauna in a drinking-water resource (Omerli Dam Lake-Istanbul, Turkey). Research journal of agriculture and biological sciences. 1(1): 50-55.

[12]. Dinseven E, Çurgunlu E (1988) Determination of the Throphic status of the Riva stream for monitoring Eutrophication. Istanbul University Journal of Fisheries \& Aquatic Sciences. 2:35-52.

[13]. Garipağaoğlu N, Şahin C, Çeker A, Şenol C (2015) Çayağzı (Riva) Basin Natural Environmental Conditions (Geological, Geomorphological-Hydrographic Perspective) and Impact on Sustainable Use - Marmara Geographical Review. 31: 48-81.

[14]. Anonymous (2000) Standard methods for the examination of water and waste water (20th ed.) DC: APHA, Washington.

[15]. MacFaddin JF (1980) Biochemical Tests for Identification of Medical Bacteria ( Second Edn) Williams and Wilkins. 